\title{
STANOVENIE EXPERIMENÁLNEJ ÚNOSNOSTI PILÓT
}

\author{
DETERMINATION OF EXPERIMENAL BEARING CAPACITY PILES
}

\author{
Ján Mihálik $^{* 1}$, Filip Gago ${ }^{1}$, Martina Buková ${ }^{1}$
}

*jan.mihalik@uniza.sk

Žilinská univerzita v Žiline, Stavebná fakulta , Katedra geotechniky, Univerzitná 8215/1, 01026 Žilina

\begin{abstract}
Abstrakt
Článok je zameraný na vyhodnotenie statickej zat'ažovacej skúšky pilót podl'a rôznych metód. Ciel'om vyhodnotenia je získat' návrhové hodnoty experimentálnej únosnosti pilót. Analýza obsahuje vyhodnotených 10 statických zat’ažovacích skúšok realizovaných na vel'kopriemerových pilótach rôznych dížok, ktoré sa nachádzajú v rovnakom inžinierskogeologickom rajóne a sú zhotovené rovnakou technológiou tzn. vítané pilóty s výpažnicou. Pri vyhodnocovaní sme sa zameriavali na najčastejšie využívané metódy a každú skúšku sme vyhodnotili podl'a STN 73 1002, podl'a metódy Brinch Hansen - 80\% kritérium a podl'a Davissonovej metódy medznej únosnosti.
\end{abstract}

\section{Klíčová slova}

Statická zat’ažovacia skúška, experimentálna únosnost', vŕtané pilóty, vyhodnotenie únosnosti

\begin{abstract}
The article is focused on the evaluation of the static load test of piles by various methods. The aim of the evaluation is to obtain design values of the experimental bearing capacity of the piles. The analysis contains evaluated 10 static load tests performed on large-diameter piles of various lengths, which are located in the same engineering geological district and are made as drilled piles with a casing. Each test is evaluated according to STN 731002 , according to the Brinch Hansen method $80 \%$ criterion and according to the Davisson method of ultimate strength.
\end{abstract}

\section{Key words}

Static load test, experimental bearing capacity, drilled piles, estimation of bearing capacity

\section{1 ÚVOD}

Posúdenie a návrh pilotových základov nie je jednoduchý proces, za najvhodnejšie sa javí navrhovanie pilót na základe medzného stavu používatel'nosti, t. j. sadnutia a ich únosnost' overit' dodatočne. Podstatne odlišný trend však môžeme vyrozumiet' z platného Eurokódu 7-1, ktorý sa venuje predovšetkým podmienkam MSÚ a sadnutie pilót spomína len okrajovo. Únosnost’ pilóty a jej presná formulácia je pomerne komplikovaná záležitost'. Únosnost' má zodpovedat' takému stavu, kedy nie je prekročená pevnost' materiálu pilóty alebo pevnost' okolitej zeminy, prípadne ich medza pretvorenia [1]. Za najspol'ahlivejší spôsob stanovenia únosnosti osamelej pilóty sa všeobecne považuje statická zat’ažovacia skúška. Pri testovaní pilóty sa zohl'adňujú aj d'alšie vplyvy, ktoré výpočtové predpoklady nemusia vždy správne vystihovat'. Do úvahy sa berú najmä vplyvy akými sú vlastnosti základovej pôdy v konkrétnej oblasti a technologické aspekty realizácie pilóty. Výsledok merania statickej zat’ažovacej skúšky sa graficky znázorňuje zat’ažovacou krivkou, ktorá zobrazuje závislost' zvislého zat’aženia a ustáleného sadania hlavy pilóty. Rovnako ako analytické metódy má aj statická zat'ažovacia skúška rôzne metódy vykonávania a vyhodnocovania experimentálneho merania poskytujúce odlišné hodnoty únosnosti ako uvádzajú autori v [2],[3],[4].

Článok analyzuje porovnanie troch metód vyhodnotenia a vzájomného porovnania výsledkov získaných zo zat’ažovacej krivky na vel'kopriemerových vítaných pilótach s použitím výpažnice. Konkrétne ide o metódy vyhodnotenia krivky podl'a STN 73 1002, metódy Brinch Hansen - 80\% kritérium a podl'a Davissonovej metódy medznej únosnosti. 


\section{STATICKÁ ZAŤAŽOVACIA SKÚŠKA PILÓTY}

Rovnako ako analytické metódy má aj statická zat’ažovacia skúška (SZS) rôzne metódy postupu a vyhodnocovania výsledkov. Pri každej metóde je nutné dodržat' určitý postup zat'ažovania pre získanie relevantnej zat'ažovacej krivky, ktorá sa následne analyzuje a určí sa výsledná únosnost' pilóty, pre ktorú sa stanoví bezpečné zat'aženie, ktorým je možné pilótu zat'ažit' bez toho, aby došlo k poškodeniu nosných konštrukcií v hornej stavbe. Najbežnejšie používanou metódou je pomalá skúška udržiavaného zat’aženia (slow ML test), označovaná ako štandardný postup zat'ažovania v ASTM navrhovaní D-1143 [5]. Na obr. 1 možno vidiet' schematickú zostavu SZS s využitím zat'ažovacieho mostu, čo je na území Slovenskej republiky najpoužívanejší spôsob. Zat’aženie na pilótu je aplikované hydraulickými lismi rozopieranými o zat’ažovací most, ktorému slúžia ako protizát’až kotviace pilóty. Najzákladnejšie meranie počas priebehu skúšky je zaznamenávanie posunu (zatlačenie) hlavy pilóty. Skúšky môžu byt' doplnené aj prídavné snímače. Napr. ide o tenzometricke snímače, poskytújúce rozsiahlejší obraz o vzájomnej interakcii pilóty a základovej pôdy. Taktiež je možné merat' priehybové (poklesové) kotliny, pomocou ktorých sa zist'uje vplyv prenášania zat'aženia do okolitého geologického prostredia.

Po vykonaní metódy zat'ažovania je potrebné krivku analyzovat' a stanovit’ z nej návrhové hodnoty. Najčastejšie používane metódy analýzy zat’ažovacej krivky sú uvedené v [6]. Problematike analýze krivky sa venovali v [2] a konštatovali, že interpretácia tej istej krivky zobrazujúcej priebeh zat'aženia a sadania môže poskytnút' vel'ký rozptyl finálnych výsledkov v závislosti od použitej metódy, a od toho ako blízko k porušeniu bola pilóta zat’ažená. Rozptyl pri niektorých metódach ovplyvňuje aj subjektívnost' inžiniera vykonávajúceho interpretáciu, pretože nie každá metóda je založená na matematických pravidlách [4].

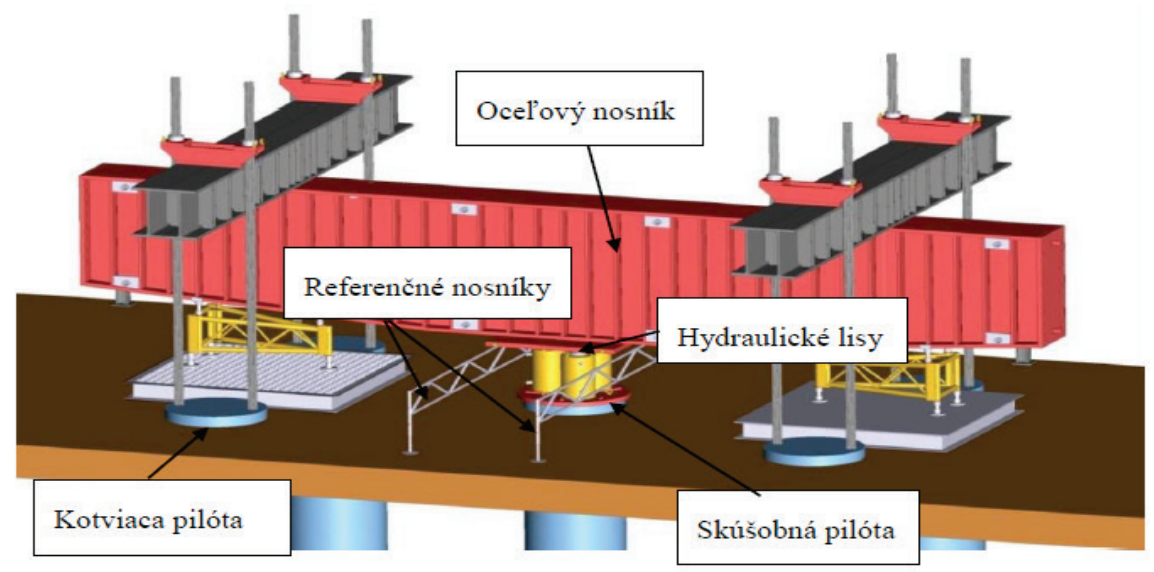

Obr. 1 Usporiadanie zat’ažovacej zostavy s kotvením do štyroch roznášacích pilót.

\section{Vyhodnotenie podl'a STN}

Na Slovensku sa najviac používa metóda, ktorú uvádza STN 731002 a určuje experimentálnu únosnost' $U_{\text {ve,i }}$ zo štyroch medzných hodnôt ( $U_{\text {con, }} U d_{\mathrm{ef}}, U_{\mathrm{pr}}$ a $\left.U_{\mathrm{y}}\right)$. Následne sa z nich určí návrhová únosnost' $U_{\mathrm{vd}}$ ako minimálna hodnota podl'a vzt'ahu:

$$
U_{v d, i}=\min \left[\frac{U_{v e, i}}{\gamma_{r e, i}}\right],
$$

kde $U_{\text {ve }}$ je experimentálna únosnost' určená z priebehu krivky [kN], $U_{\mathrm{vd}}$ je návrhová únosnost' $[\mathrm{kN}], \gamma_{\mathrm{re}, \mathrm{i}}$ je parciálny súčinitel' zohl'adňujúci bezpečnost' návrhu.

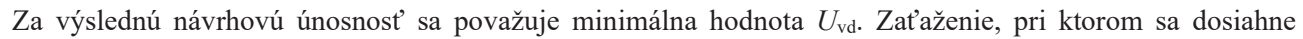

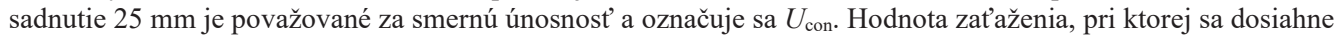
sadanie $0,1 D$ je považovaná za únosnost' na medzi pretvorenia $U_{\text {def. }}$ Zat'aženie, pri ktorom nastane väčšia zmena zakrivenia zat'ažovacej krivky, sa považuje za únosnost' na medzi úmernosti $U_{\text {pr }}$. $U_{\mathrm{y}}$ predstavuje únosnost' na medzi pretvorenia, ide o hodnotu pri ktorej sa dosiahne zretel'ný zlom na zat'ažovacej krivke. Ak sa nedosiahne 
ani jedna z uvedených hodnôt za charakteristickú únosnost' sa považuje najväčšia hodnota zat’aženia počas SZS [7].

\section{Vyhodnotenie podl'a Brinch Hansen 80\% kritérium}

J. Brinch Hansen v roku 1963 definoval únosnost’ pilóty $Q_{\mathrm{u}}\left(U_{\mathrm{ve}}\right)$ ako zát’až, ktorá vyvoláva štvornásobok sadania hlavy pilóty získaného pri 80 \% tejto zát’aži. Toto $80 \%$ kritérium možno odhadnút' priamo z krivky sadania a zat'aženia, ale presnejšie je určené v grafe závislosti odmocniny každej hodnoty sadania podelenej príslušnou hodnotou zat’aženia a samotného sadania $\left(\sqrt{ } S / V\right.$ a $S$ ). V tomto grafe sa následne určia parametre $C_{1}$ a $C_{2}$ z koncovej priamkovej časti grafu.

$$
\begin{gathered}
Q_{u}=\frac{2}{2 * \sqrt{C 1 * C 2}}, \\
S_{u}=\frac{C_{2}}{C_{1}},
\end{gathered}
$$

kde $Q u$ je charakteristická únosnost’ určená z priebehu krivky [kN], $S_{\mathrm{u}}$ je sadnutie pilóty pri $Q u[\mathrm{kN}], C_{1}$ je číselné vyjadrenie sklonu priamky, $C_{2}$ je ypsilónová súradnica začiatku priamky.

Pri použití metódy Brinch Hansen $80 \%$ kritérium je dôležité skontrolovat' či bod 0,80 Qu/0,25Su leží v blízkosti krivky alebo na nameranej krivke sadania a zat'aženia. Relevantnost' hodnotenia sa môže prehodnotit' tak, že nameraná krivka sadania a zat’aženia sa prekryje vypočítanou krivkou podl'a rovnice (4). Tieto dve krivky by mali byt' v tesnej blízkosti zat'aženia rovnajúceho sa približne $80 \%$ z $Q_{\mathrm{u}}$ a samotného konečného zat'aženia (únosnosti) $Q_{\mathrm{u}}[8]$.

$$
V_{v}=\frac{\sqrt{S}}{C_{1} * S+C_{2}},
$$

kde $V_{\mathrm{v}}$ je vypočítané zataženie $[\mathrm{kN}], S$ je sadanie $[\mathrm{mm}]$.

\section{Vyhodnotenie podl'a Davissonovej metódy medznej únosnosti}

Davisson definoval únosnost' pilóty $Q_{\mathrm{u}}\left(U_{\mathrm{ve}}\right)$ ako zát'až zodpovedajúcu sadaniu, ktoré presahuje elastické stlačenie (skrátenie) pilóty $\Delta$ o hodnotu $4 \mathrm{~mm}$ plus faktor rovný priemeru pilóty $D$ (v milimetroch) delený 120 . Medzná únosnost' pilóty sa určí priamo z grafu závislosti sadania $\mathrm{S}$ a zat'aženia $V$. Za únosnost' pilóty sa podla Davissonovej metódy považuje bod, kde pretne odsadená čiara elastického skrátenia o hodnotu $X_{\mathrm{d}}$ krivku závislosti sadania a zat’aženia získanú zo statickej zat’ažovacej skúšky. Elastické skrátenie pilóty $\Delta$ a jeho odsadenie $X_{\mathrm{d}}$ sa vypočítajú podl'a vzt'ahov (5) a (6). $\Delta$ a $X_{\text {d }}$ sa počíta pre každý stupeň zat'aženia [3], [9]

$$
\Delta=V * \frac{L}{-}(E * A),
$$

kde $\Delta$ je elastické stlačenie pilóty $[\mathrm{mm}], \quad V$ je aplikované zat’aženie $[\mathrm{kN}], L$ je dížka pilóty $[\mathrm{m}], A$ je plocha priečneho rezu pilóty $\left[\mathrm{m}^{2}\right], E$ je modul pružnosti materiálu piloty $[\mathrm{kPa}]$

$$
X_{d}=4 m m+\frac{D}{120}
$$

kde $X_{\mathrm{d}}$ je odsadenie elastického skrátenia pilóty [mm], $D$ je priemer pilóty [mm].

\section{Stanovenie návrhovej únosnosti}

Návrhová únosnost' $U_{\mathrm{vd}}$ sa stanovuje podelením experimentálnej únosnosti pilóty $U_{\mathrm{ve}}$ koeficientom bezpečnosti $\gamma$. Tu však treba dat' pozor, koeficient bezpečnosti $\gamma$ nie je jednotná hodnota uplatnitel'ná za každých okolností. Jeho hodnota závisí od dovolenej úrovne zlyhania, ako aj od úrovne kontroly aspektov ovplyvňujúcich zmenu únosnosti pilóty na danom mieste. Ovplyvňuje ho aj metóda, ktorá sa používa na vyhodnotenie výsledkov skúšky. Vel’a noriem určuje jednotný koeficient bez ohl'adu na podmienky, zvyčajne je to hodnota 2,0 často aj vyššia [3]. Vol'nost' inžinierov pri navrhovaní pilót viedla k použitiu vel'kého množstva koeficientov bezpečnosti. Pri zat’ažovacej skúške vykonanej na začiatku projektových práce, kedy nie je isté, že pilóta bude rovnakého druhu sa používajú hodnoty 2,5 . V prípade testovania počas konečnej konštrukčnej fázy, ked' sa zat'ažovacia skúška uskutoční za priaznivých podmienok reprezentatívnych pre projekt sa používajú hodnoty 1,8-2,2. 
Metóda STN uvádza rozmedzie koeficientu bezpečnosti $\gamma$ v rozsahu od 1,0-1,5 a to v závislosti od dosiahnutej medznej hodnoty(v našom prípade je to pri pilótach č. 1 až 7 a 10 hodnota 1,5; pri pilótach č. 8 a 9 je to hodnota $1,3)$. Koeficient bezpečnosti $\gamma$ pre Davissonovú metódu sa zvyčajne volí v rozsahu 1,8 až 2,0 . Vo výpočtoch je uvažované s hodnotou 2,0. Pri metóde Brinch Hansen - 80\% kritérium je pre určenie návrhového zat'aženia koeficient bezpečnosti $\gamma$ zvyčajne v rozsahu 2,0-2,5 [6]. V našich analýzach sme uvažovali s hodnotou 2,0.

\section{VYHODNOTENIE ZAŤAŽOVACÍCH KRIVIEK}

Ako podklad pre hodnotenie slúžia výsledky zo skúšok realizovaných na pilótach, ktoré sú súčast’ou základov stavebných mostných objektov SO 201 a SO 202 situované na ceste I/51, Trnava, severný obchvat. Realizácia a postup zvyšovania zat'aženia na pilótu počas SZS bol realizovaný podl’a [7]. Maximálne skúšobné zat’aženie na pilótu bolo stanovené ako 1,5 násobok návrhového zat’aženia poskytnutého statikom hornej stavby. V článku je vyhodnotených 10 statických zat’ažovacích skúšok podl’a [7], [8], [9]. Všetky pilóty boli zhotovené z betónu triedy C30/37 ako vŕtané pilóty s výpažnicou a CFA technológiou (pilóty s priemerom $1,0 \mathrm{~m}-\mathrm{CFA}$, pilóty s priemerom $1,2 \mathrm{~m}$ - vŕtané). Dížky, priemery, triedy betónu, inžiniersko-geologické profily, v ktorých sa pilóty nachádzajú a priebehy statických zat’ažovacích skúšok sú prevzaté z [10]. Na obr. 2 možno vidiet’ priebeh sadania jednotlivých pilót v závislosti od zat'aženia.

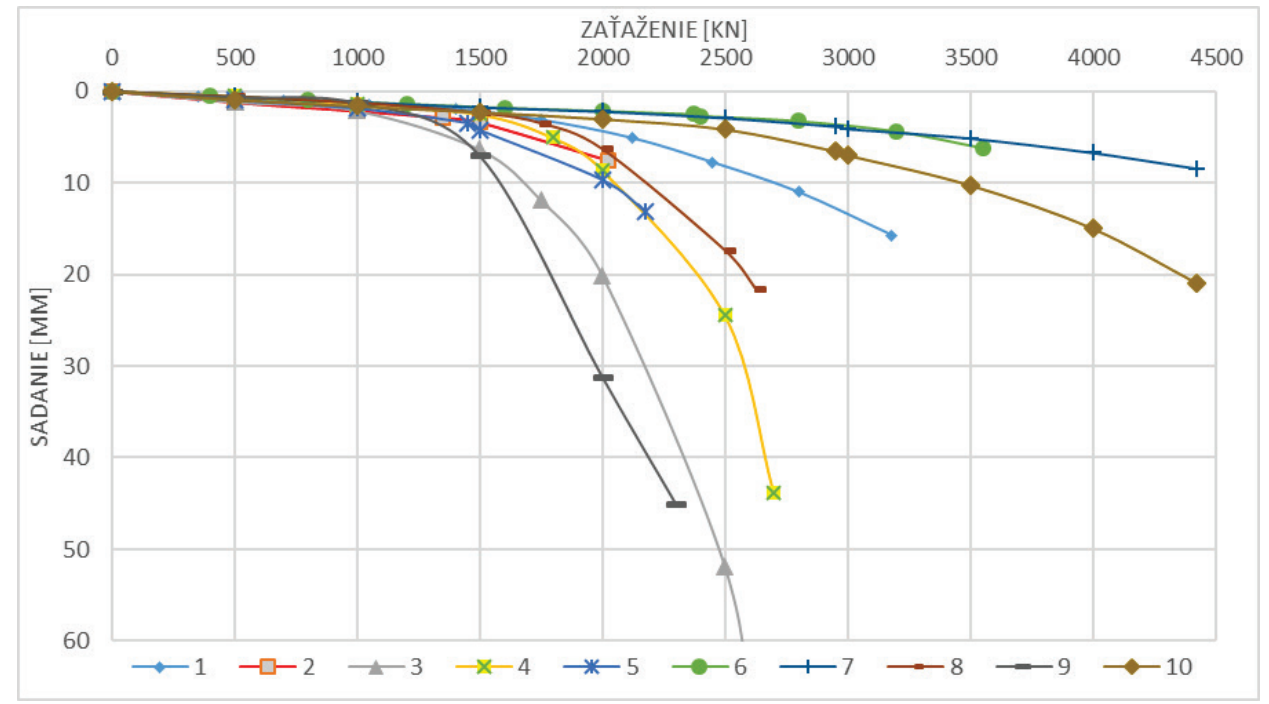

Obr. 2 Zat’ažovacie krivky závislosti zat’aženia a sadania pre pilóty č. 1 až 10.

Unikátnost' výsledkov statických zat'ažovacích skúšok tkvie v tom, že sú všetky realizované na jednej lokalite, na pomerne malej ploche. Podla geomorfologického členenia patrí skúmané územie do celku Podunajská pahorkatina, podcelku Trnavská pahorkatina, časti Trnavská tabul'a a ide o rovinaté uzemie. Povrch terénu sa pohybuje od 153,85 do 154,29 m n. m. Skúmané územie je budované na povrchu prevažne preplavenými sprašovými ílmi a v nižších polohách s výskytom fluviálnych pieskov. Hladina podzemnej vody kolíše okolo $10,5 \mathrm{~m}$ pod povrchom terénu vo vrstvách fluvialnych pieskov.

Geológia územia je tvorená:

- ornicou a humusom hrúbkou vrstvy $0,3-0,5 \mathrm{~m}$,

- podorničnou vrstvou s hrúbkou $0,3-0,8 \mathrm{~m}$ siltovitého charkateru,

- vrstvami spraší so strednou a nízkou plasticitou triedy F6 tuhej miestami pevnej až tvrdej konzistencie, slabo presadavé až presadavé, hrúbka vrstvy 9,0-9,4 m,

- fluviálnymi sedimentami, ktoré majú charakter piesku ílovitého tr. S5 a piesku s prímesou jemnozrnnej zeminy S3 s hrúbkou vrstvy 1,0-2,6 m,

- $\quad$ spodné vrstvy sú tvorené neogénymi sedimentami charakteru ílu s vysokou plasticitou tr. F8/CH. 
V Tab. 1 sú uvedené identifikačné údaje pilót a výsledky z vyhodnocovania statických zat’ažovacích skúšok (návrhové únosnosti). Grafické vyhodnotenie možno vidiet’ na obr. č. 3. Päty pilot sú ukončené v únosnějších vrstvách pieskov triedy S3 a S5 s výnimkou pilóty č. 6, ktorej päta konči v sprašovitých zeminách.

Tab.1 Špecifikácií pilót a výsledných únosností.

\begin{tabular}{ccccccccc}
\hline $\begin{array}{c}\text { Č́́slo } \\
\text { pilóty }\end{array}$ & Objekt & $\begin{array}{c}\text { Umiest } \\
\text { nenie }\end{array}$ & $\begin{array}{c}\text { Priemer } \\
\mathbf{D}[\mathbf{m}]\end{array}$ & $\begin{array}{c}\text { Dížka } \\
\mathbf{L}[\mathbf{m}]\end{array}$ & $\begin{array}{c}\text { STN 73 1002 } \\
\mathbf{U}_{\mathbf{~ v d}}[\mathbf{k N}]\end{array}$ & $\begin{array}{c}\text { Brinch Hans. } \\
\mathbf{8 0 \%} \mathbf{U}_{\mathbf{v d}}[\mathbf{k N}]\end{array}$ & $\begin{array}{c}\text { Davisson } \\
\mathbf{U}_{\mathbf{v d}}[\mathbf{k N}]\end{array}$ & $\begin{array}{c}\text { Návrh. } \\
\text { zat'až. }\end{array}$ \\
\hline 1 & SO-201 & opr.1 & 1,2 & 14,0 & 2120,0 & 1768,0 & 1575,0 & 2120 \\
2 & SO-201 & pod. 2 & 1,0 & 8,6 & 1350,0 & Neurčené & Neurčené & 1350 \\
3 & SO-201 & pod. 3 & 1,0 & 8,6 & 1750,0 & 1318,0 & 905,0 & 1750 \\
4 & SO-201 & pod. 4 & 1,0 & 8,6 & 1800,0 & 1318,0 & 1088,0 & 1800 \\
5 & SO-201 & pod. 5 & 1,0 & 8,6 & 1450,0 & 1185,0 & 1086,0 & 1450 \\
6 & SO-201 & opr.6 & 1,2 & 17,5 & 2370,0 & Neurčené & Neurčené & 2370 \\
7 & SO-202 & opr.1 & 1,2 & 16,3 & 2950,0 & Neurčené & Neurčené & 2950 \\
8 & SO-202 & pod. 2 & 1,0 & 8,8 & 1606,0 & 1250,0 & 1161,0 & 1750 \\
9 & SO-202 & pod. 3 & 1,0 & 8,8 & 1077,0 & 1141,0 & 822,0 & 2300 \\
10 & SO-202 & opr. 4 & 1,2 & 15,7 & 2950,0 & 2795,0 & 2042,0 & 2950 \\
\hline
\end{tabular}

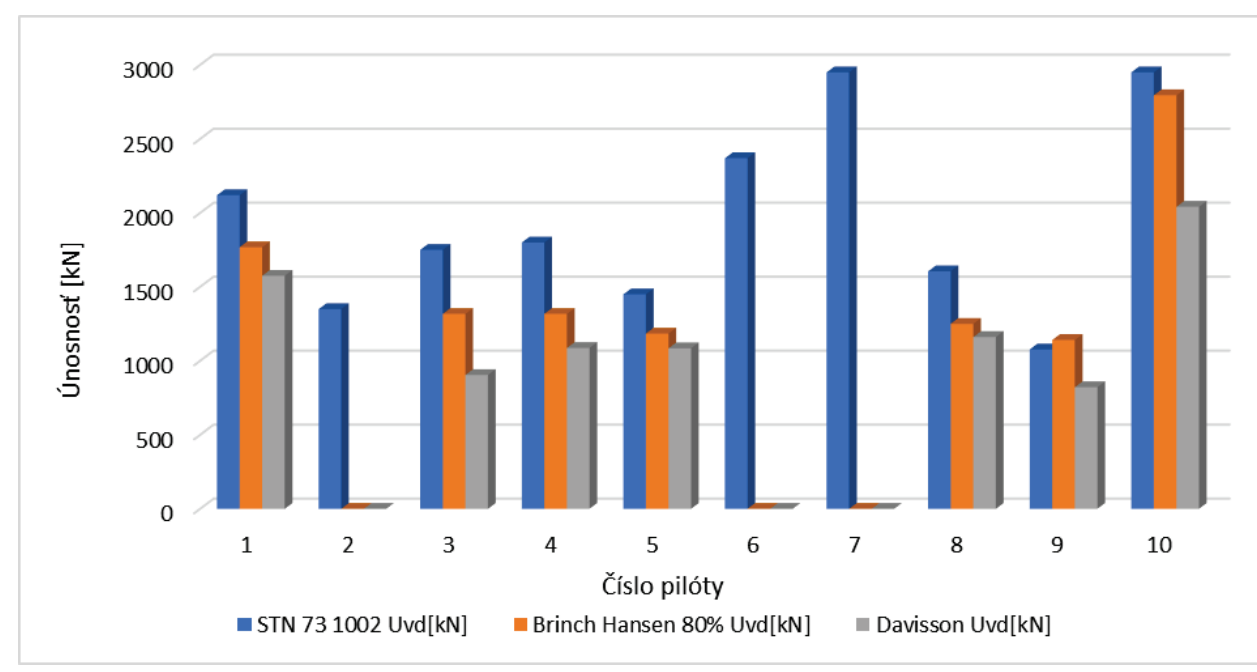

Obr. 3 Graf vyhodnotenia únosnosti pilóty.

Podl'a metódy STN 731002 bolo možné zistit’ únosnosti pre všetky pilóty. V deviatich prípadoch bola zistená návrhová únosnost' rovnaká ako návrhová hodnota zat’aženia, pretože rozhodujúca experimentálna únosnost' $U_{\mathrm{v}, \mathrm{e}}$ bola rovná maximálnemu skúšobnému zat’aženiu. Pre pilótu č. 9 bola únosnost' nevyhovujúca.

Podl'a metódy Brinch Hansen $80 \%$ kritérium bolo možné zistit' únosnosti pre 7 pilót. Vo všetkých 6 prípadoch boli únosnosti menšie ako návrhové hodnoty zat'aženia. Úusnost' pilóty č. 2 a 7 nebola určená, pretože koncové body grafu závislosti $S$ a $\sqrt{ } S / V$ netvorili priamku $\left(\mathrm{R}^{2}<0,7\right)$. Ĺwsnost' pilóty č. 6 nebola určená, pretože bod $0,8 Q_{\mathrm{u}} / 0,25 S_{\mathrm{u}}$ ležal mimo rozsahu nameranej krivky.

Podl'a Davissonovej metódy medznej únosnosti bolo možné zistit' únosnosti pre tých istých 7 pilót ako podl'a metódy Brinch Hansen $80 \%$ kritériá. V šiestich prípadoch boli únosnosti menšie ako návrhové hodnoty zat'aženia. Úmsnost' pilót č. 2, č. 6 a č. 7 nebolo možné určit', pretože elastické skrátenie pilót $\Delta$ odsadené o hodnotu $X_{\mathrm{d}}$ bolo väčšie ako sadanie pilót.

Pri porovnaní metódy STN 731002 s metódou Brinch Hansen 80\% kritérium sú únosnosti pilót v šiestich prípadoch menšie. Rozdiel únosnosti v percentuálnom porovnaní sa pohybuje v rozsahu 6-37 \%, v priemere je to hodnota $24 \%$. Iba v jednom prípade bola únosnost' pilóty väčšia, a to pri pilóte č. 9 , kedy predstavovala výslednú únosnost' väčšiu o $6 \%$.

Pri porovnaní metódy STN 731002 s Davissonovú metódou medznej únosnosti sú únosnosti pilót vo všetkých prípadoch menšie. Rozdiel únosnosti v percentuálnom porovnaní sa pohybuje v rozsahu 31-93 \%, v priemere je to hodnota $52 \%$. 


\section{ZÁVER}

Výsledok statickej zat’ažovacej skúšky neposkytuje jednoznačné odpovede stanovenia únosnosti pilóty. Existujú značné odchýlky v metódach interpretácie zlyhania či prekročenia únosnosti. Z tohoto dôvodu je nutné prihliadnut' aj na limitné hodnoty sadnutia pilóty pri danej únosnosti, ktoré by mohli ohrozit’ stabilitu konštrukcie. Statická zat’ažovacia skúška, ktorá meria iba aplikované zat'aženie a pohyb hlavy pilóty nám vyjadruje únosnost' pilóty ako celku bez možnosti stanovenia samostatnej únosnosti päty a plášta pilóty, avšak pri malých projektoch je takáto úroveň náročnosti postačujúca, ak je neistota pokrytá dostatočným faktorom bezpečnosti.

Vyhodnotením výsledkov experimentálnych meraní môžeme konštatovat', že metóda STN je univerzálna, ked’že je možné určit' únosnost' pre každý typ zat'ažovacej krivky, tiež poskytuje najväčšie hodnoty únosnosti $\mathrm{z}$ troch uvedených metód, iba $\mathrm{v}$ jednom prípade hodnota bola menšia ako Brinch Hansen- $80 \%$ kritérium. Nevýhodou je však, že metóda nie je plne založená na matematickom pravidle, ktoré by generovalo stále rovnakú hodnotu nezávisle na mierke zobrazenia, čo neplatí však napr. pri stanovení $U_{\mathrm{pr}}$ a $U_{\mathrm{y}}$. Tiež by poskytovala odlišné výsledky, ak by zat'ažovanie pilóty pokračovalo na väčšie hodnoty.

Metódy Brinch Hansen $80 \%$ kritérium a Davissonovú metódou medznej únosnosti nemôžme považovat' za univerzálne metódy, ked'že nebolo možné stanovit’ únosnost' pre všetky typy zat’ažovacích kriviek. Nie je možné ich použit' pre krivky, pre ktoré je typické malé sadanie s narastaním zataženia a malé konečné sadnutie pri maximálnom skúšobnom zat’ažení.

\section{Použité zdroje}

[1] STACHO, J. Analýza navrhovania pilót so zohl’adnením technológie zhotovovania, dizertačná práca, STU Bratislava STU 2015

[2] DE COCK, F. - LEGRAND, C. - HUYBRECHTS, N. 2003. : Overview of design methods of axially loaded piles in Europe - Report of ERTC3-Piles, ISSMGE Subcommittee. In XIIIth European conference on soil mechanics and geotechnical engineering: proceedings. Vol 3. Geotechnical problems with man-made and man influenced grounds. Prague: The Czech Geotechnical Society CICE, 2003. ISBN 80-86769-02-X.

[3] FELLENIUS, B. H. 2001. We have determined the capacity, then what? [online]. New Jersey: Deep Foundation Institute, Fulcrum, 2001. 4 p. Dostupné na internete: https://www.fellenius.net/papers/230\%20\&\%20240\%20Analysis\%20of\%20Pile\%20Capacity-DFI.pdf

[4] FELLENIUS, B. H. 2001. What capacity value to choose from the results a static loading test [online]. New Jersey: Deep Foundation Institute, Fulcrum, 2001. 4 p. Dostupné na internete:

https://www.fellenius.net/papers/230\%20\&\%20240\%20Analysis\%20of\%20Pile\%20Capacity-DFI.pdf

[5] Astm D1143-81 Piles Under Static Compressive Axial Load

[6] DIŇA, N. Hodnotenie statickej zat’ažovacej skúšky pilót podl’a rôznych postupov [bakalárska práca]/; Škol. Giang Nguyen, . - Katedra geotechniky Fakulty stavebnej Žilinskej univerzity v Žiline. - Žilina; 2018. - $89 \mathrm{~s}$

[7] STN 73 1002: 1987: Pilotové základy

[8] Hansen, J.B., 1963. Discussion on hyperbolic stress-strain response. Cohesive soils. American Society of Civil Engineers, ASCE, Journal for Soil Mechanics and Foundation Engineering, Vol. 89, SM4, pp. $241-242$.

[9] Davisson, M. T., 1972. High capacity piles. Proceedings of Lecture Series on Innovations in Foundation Construction, American Society of Civil Engineers, ASCE, Illinois Section, Chicago, March 22, pp. 81 - 112.

[10] DRUSA, M. - KORENKO, M. 2010 - 2011. Dokumenty „PROJEKT ZAŤAŽOVACEJ SKÚŠKY PILÓTY“ a „VYHODNOTENIE ZAŤAŽOVACEJ SKÚŠKY PILÓTY“ pre pilóty SO 201 - SO 202. 